\title{
Nutritional Characteristics (Fatty Acid Profile, Proximate Composition and Dietary Feature) of Selected Nuts Available in Local Market
}

\author{
Nusrat N. Memon ${ }^{*}$, Samina Kanwal ${ }^{1}$, Farah N. Talpur ${ }^{2}$, Hassan I. Afridi ${ }^{2}$, \\ G. Zuhra Memon ${ }^{1}$, M. Q. Samejo ${ }^{1}$, Jamil R. Memon ${ }^{1}$ and Humaira Khan ${ }^{1}$ \\ ${ }^{1}$ Dr. M.A. Kazi Institute of Chemistry, University of Sindh, Jamshoro, Pakistan. \\ ${ }^{2}$ National Centre of Excellence in Analytical Chemistry, University of Sindh, Jamshoro, Pakistan. \\ *Corresponding Author Email: nusratmemon2007@yahoo.com \\ Received 13 Mach 2019, Revised 19 June 2019, Accepted 25 June 2019
}

\begin{abstract}
The present work describes fatty acid profile, proximate composition and nutritional quality of selected nuts (Almond, Pistachio, Walnut, Pine nut and Peanut). Differences $(\mathrm{p}<0.05)$ were noticed in the crude protein (17.85-31.17\%), total lipids (49.81-66.96\%), carbohydrate (1.46$14.14 \%)$, moisture $(2.50-4.50 \%)$ and ash (1.50-3.60\%) contents of the nuts. The palmitic acid and stearic acid were the main saturated fatty acids (SFA), oleic acid was the predominant monounsaturated fatty acids (MUFA), while the linoleic and linolenic acid were the major polyunsaturated fatty acids (PUFA). The percentage of linoleic acid exceeded that of linolenic acid in all analyzed nut samples. A major finding of LC-PUFA (Long Chain PUFA) among walnut was found higher $(72.14 \mathrm{~g} / 100 \mathrm{~g})$, due to higher linoleic and linolenic acid (57.26 and 14.88 $\mathrm{g} / 100 \mathrm{~g}$ ). In addition the calculated essential PUFA/SFA ratio was ranged as 3.10-11.49. However ratio of $n-6 / n-3$ FA ranged 3.83-11.05, lower $n-6 / n-3$ for walnut is beneficial for nutrition purpose by providing more $n-3$ essential FAs in comparison of other analyzed nuts. The results showed that all selected nuts have good nutritional quality and could be used in fighting malnutrition and can serve as valuable source of oil for industrial purposes.
\end{abstract}

Keywords: Edible nuts, Proximate composition, Fatty acid profile, Nutritional values and Gas chromotography.

\section{Introduction}

From earliest times the nuts were most important and nutritious food for humans, they were inspired globally for their nutritional quality and health promoting characteristics. In general nuts are dry fruits composed of a hard shell and seed [1]. Nuts were nurtured for the oil crops, as imperative source of energy and essential food nutrients. They are very nourishing and contain a significant quantity of vital minerals, proteins, carbohydrate, vitamins, fiber, steroids, phytochemicals, micronutrients and tocopherols which make them superior substitute for human groceries [2]. In addition nuts are excellent source of fats and edible oils affluent in vital (LC-PUFA) long chain polyunsaturated fatty acids. Percentage of PUFA in nuts comprised up to $78 \%$ due to greater contents of linoleic and linolenic acid FA are necessary in human diet for growth maintenance and reproduction [3]. On the basis of health benefits regular consumption of nuts are responsible to minimize the threat of coronary heart disease (CHD), cancer, type-2diabetes, inflammation and several other chronic diseases. Nuts also contain good amount of oleic acid, having great importance due to their positive effects on blood 
cholesterol reduction, increases the HDL (good cholesterol) and reduces LDL (bad cholesterol) [4].

Nuts are also commercially and economically valuable. They are important for industrial uses, medicinal, cosmetic as well as pharmaceutical companies, traditional dishes and food industries in breads, cakes, cookies, sauces, candies, muffins, biscuits, vegetable and meat dishes [5]. It is consumed in confectionery because of the different color, texture and flavor of kernel; lipid compositions of nut oils are also components of some soups, skin moisturizers and other products [6]. The nutritional and chemical composition of nuts depends on different factors, which influence the quality and quantity of macro and micronutrients of nuts. Nutritional quality of the edible nut is strongly influenced by geographical location, season, particularly soil, water, temperature, relative humidity and light, genetic, ecological, morphological, physiological and cultural factors which also affects the crop growth and seed maturation [7]. Keeping in view the above facts, current study was carried out to determine fatty acid profile, proximate composition and nutritional quality of commonly consumed nuts (Almond, Walnut, Pistachio, Pine nut and Peanut) in Sindh, Pakistan.

\section{Materials and Methods \\ Sample collection \\ Determination of proximate composition}

Selected edible nuts such as Walnut (Juglansregia), Almond (Prunusduclis), Pistachio (Pistaciavera), Peanut (Arachis hypogeal) and Pine nut (Pinuspinea) of premium quality were collected from the standard shop of retail market Hyderabad Pakistan by checking their size, color, taste, flavor, humidity and fungi. The food quality assurance (QA) and quality control (QC) were managed by Pakistan Standards and Quality Control Authority (PSQCA) system [8]. Fifteen samples of each type were collected, stored in plastic bag and chemical analyses were repeated three times.

Proximate composition of selected nuts was determined by the official methods of the AOAC [9]. Total protein were calculated by
Kjeldahl method, 6.025 factor were used for the conversion of protein, ash were determined by direct analysis in muffle furnace for $12 \mathrm{~h}$ at $550^{\circ} \mathrm{C}$, moisture content were calculated by the oven drying method for $6-7 \mathrm{~h}$ at $110^{\circ} \mathrm{C}$ temperature and total lipid was extracted by Soxhlet method. Carbohydrate content was calculated by difference between 100 and the sum of the lipid, protein, moisture and ash. Energy value was calculated by using individual calorie factor of lipid, protein and carbohydrates.

\section{Fatty acid analysis}

According to IUPAC method no 2.301 [10], the lipids were saponified and esterified for FA analysis. The fatty acid methyl esters (FAMEs) were investigated on a gas chromatograph (model 8700 Perkin-Elmer Ltd, Buckinghamshire, England) fixed with SP-2340 stationary-phase (biscynopropyl siloxane), $[(60 \mathrm{~m} \times 0.25 \mathrm{~mm})$ Supelco, PA, USA] with FID. Oxygen-free nitrogen was used as a carrier gas at a flow rate of $3.5 \mathrm{~mL} / \mathrm{min} .150^{\circ} \mathrm{C}$ was the starting temperature of oven were elevate to $190^{\circ} \mathrm{C}$ at a speed of $4^{\circ} \mathrm{C} / \mathrm{min}$, and more to $220^{\circ} \mathrm{C}$ at a speed of $2{ }^{\circ} \mathrm{C} / \mathrm{min}$ and detained for $7 \mathrm{~min}$. The detector and injector temperatures were set at 270 and $260{ }^{\circ} \mathrm{C}$, correspondingly. $2.0 \mu \mathrm{L}$ of FAME were injected. Identification of FAMEs was done by comparing their absolute and retention times with (Sigma Chemical Co) FAME standards. The quantification was done by a built-in data-handling program given by the PerkinElmer company of the gas chromatograph.

\section{Results and Discussion Proximate composition}

Table 1 shows the proximate compositions of selected nuts. The significant differences $(p<0.05)$ were confirm through the study for different nuts studied in terms of proximate composition. Lipid was predominate component in all analyzed nuts, play vital role in human body by providing essential FAs and energy which are health beneficial for human [11]. The highest contents of lipid were observed in pine nuts (66.96\%) followed by walnut (63.37), almond (62.25), pistachio (60.82) and lowest were found in 
peanut $(49.81 \%)$. These results were comparing favorably with several reported results of lipid in different nuts from Portugal [12], Turkey [13], Bulgaria [14] and Iran [15]. It was considered that the variation in the lipid content of different analyzed nuts is due to several reasons like different rising regions, rising conditions, season, rootstocks, irrigation as pointed out by Abdoshahi et al., [16].

Among the studied edible nuts protein content was found the second major component after lipid contents. Table 1, indicates that the maximum mean value of protein was found in walnut $(31.17 \%)$ followed by almond $(29.37 \%$, peanut $(28.79 \%)$ and pine nut $(26.22 \%)$, however lower amount of protein content was calculated in pistachio $(17.85 \%)$. The results of protein content in pistachio were in agreement with values of protein of different varieties of pistachio as16.26 to $20.70 \%$ pointed out by [16], similarly another author Soheila et al., [17] has reported 18.81-19.31 $\%$ of protein in pistachio nuts, however Angela et al., [18] worked on protein content of different nuts and found maximum level of protein $20.54 \%$ in pistachio, as compared to 9.13 to $19.10 \%$ pecan to cashew nuts. Similarly in 2015 Laura et al.,[19] reported higher amount of protein $(24.50 \%)$ in pistachio as compared to present study. According to Cevdet \& Iclal [20] the protein content of pine nut was $31.60 \%$, which is higher in response to our study, however current results of pine nut protein $(26.22 \%)$ were comparable to the protein content of pine nuts described earlier [12] which ranged $14.06 \%$ to $28.85 \%$. Protein content for almond was also found higher in reported research in comparison to present study (29.37\%) such as, Akpabio, [21] reported content of almond protein as $33.69 \%$ and Olatidoye et al., [22] reported $(32 \%)$ of protein from almond nut. In current analysis walnut were found significantly higher in protein content than other studied nuts. According to Udedi et al., [23] percentage of protein from raw walnut was $23.01 \%-28.00 \%$, it was found lower in contrast to present results. Depending on the nut type, there was a significant variation in protein content. Moreover it is established that the variation in protein content depends on cultivars and growing location [21].

Selected nuts samples had low moisture percent values ranging from 2.50 to $4.50 \%$. Low moisture content is crucial for keeping quality and shelf life of edible nut samples and it reduces the probability of microbial growth, premature seed germination, unwarranted fermentation and minimizing the risk of aflatoxin production [24], present results of moisture content are correlated with reported results [25].

Ash content ranged from 1.5 to $3.60 \%$ for walnut to peanut; Aooyla et al., [6] reported similar results for ash content of different edible nuts. Nuts are main concentrated source of energy due to higher lipids laure et al., [19] has confirmed that the $80 \%$ energy value in nuts is derived due to lipids, $18 \%$ from protein and $2 \%$ from carbohydrates. Hence in present study highest calorific value was found for pine nuts (713.48 $\mathrm{kcal})$, and lower caloric value was found for peanut (620.01 kcal).

Table 1. Proximate composition of five different nuts (\%, wet basis).

\begin{tabular}{|c|c|c|c|c|c|c|}
\hline Nuts & Moisture & Ash & Lipid & Protein & Carbohydrate & $\begin{array}{c}\text { Energy (kcal) } \\
\text { g/100g } \\
\end{array}$ \\
\hline Walnut & $2.50^{\mathrm{a}} \pm 0.03$ & $1.50^{\mathrm{b}} \pm 0.01$ & $63.37^{\mathrm{c}} \pm 0.03$ & $31.17^{\mathrm{a}} \pm 0.09$ & $1.46^{\mathrm{b}} \pm 0.03$ & $700.85^{\mathrm{a}} \pm 0.01$ \\
\hline Almond & $3.00^{\mathrm{b}} \pm 0.01$ & $2.50^{\mathrm{a}} \pm 0.08$ & $62.25^{\mathrm{a}} \pm 0.04$ & $29.37^{\mathrm{c}} \pm 0.05$ & $2.88^{\mathrm{c}} \pm 0.01$ & $687.25^{\mathrm{a}} \pm 0.03$ \\
\hline Pistachio & $4.50^{\mathrm{d}} \pm 0.05$ & $2.80^{\mathrm{c}} \pm 0.09$ & $60.82^{\mathrm{b}} \pm 0.01$ & $17.85^{\mathrm{a}} \pm 0.03$ & $14.03^{\mathrm{a}} \pm 0.02$ & $674.90^{\mathrm{b}} \pm 0.05$ \\
\hline Peanut & $3.66^{\mathrm{c}} \pm 0.07$ & $3.60^{\mathrm{d}} \pm 0.01$ & $49.81^{\mathrm{a}} \pm 0.02$ & $28.79^{\mathrm{d}} \pm 0.01$ & $14.14^{\mathrm{d}} \pm 0.01$ & $620.01^{\mathrm{c}} \pm 0.08$ \\
\hline Pine nut & $2.83^{\mathrm{a}} \pm 0.02$ & $2.50^{c} \pm 0.01$ & $66.96^{\mathrm{b}} \pm 0.05$ & $26.22^{\mathrm{b}} \pm 0.02$ & $1.49^{\mathrm{c}} \pm 0.01$ & $713.48^{\mathrm{b}} \pm 0.02$ \\
\hline
\end{tabular}

Note: Each value is an average of fifteen samples, with its standard deviations. Different superscripts in the same column indicate significant differences $(\mathbf{p}<0.05)$ 


\section{Fatty acid composition}

Table 2 shows the FA compositions of nuts. Calculated results vary significantly $(\mathrm{p}<0.05)$ in terms of saturated and unsaturated FA; all samples contained higher amount of unsaturated fatty acid, as three nuts (almond, pistachio and peanut) contained predominantly monounsaturated fatty acid (MUFA) while two nuts (walnut and pine nut) contained predominantly polyunsaturated fatty acids (PUFA). Our results are consistent with the published results for different nuts by Dorota $e t$ al,. [26]. Among the total SFAs, palmitic acid was the predominant FA in all analyzed nut samples comprised 10.22, 5.37, 5.70, 4.54 and $4.36 \mathrm{~g} / 100 \mathrm{~g}$ of total SFA in the peanut, pistachio, almond, pine nuts and walnut correspondingly. Hulya et al., [27] also reported palmitic acid as main SFA among nuts, ranged 5.42 to $7.29 \mathrm{~g} / 100 \mathrm{~g}$. Similarly Mahesh $\&$ Shridhar [28] reported related values.

Higher MUFA content was observed in almond (60.95 g/100g) lower in walnut (21.43 g/100g). Angela et al., [18] reported comparable MUFA of different edible nuts ranged 18.7 to $77.51 \mathrm{~g} / 100 \mathrm{~g}$. Present results of almonds were comparable with previous reported data of almond by Safa et al., [29] in Turkey showing $60.18 \%$ of MUFA. Huseyin et al., [30] in 2014 also worked on different genotypes of almond and reported comparable limit of MUFA i.e. $61.80 \mathrm{~g} / 100 \mathrm{~g}$. Similarly, Vassilia et al., [31] determined MUFA contents for walnuts in Greece ranged (19.96 to $20.59 \mathrm{~g} / 100 \mathrm{~g})$. Cemile et al., [32] described
MUFA for different walnut genotypes grown in Turkey which falls within the range of 18.15 to $34.62 \mathrm{~g} / 100 \mathrm{~g}$. The variation among MUFA content in different analyzed nuts is greatly depending on the level of oleic acid. In present work oleic acid occur as most abundant MUFAs in analyzed nuts followed by palmitolic acid. Almond showed the maximum percentage of oleic acid $(60.25 \mathrm{~g} / 100 \mathrm{~g})$ while lowest for walnut $(21.23 \mathrm{~g} / 100 \mathrm{~g})$. These outcomes are in accord with previously mentioned results of nuts described by Safa et al., [29] and Mahesh and Shridhar [28]. Other researchers Jae et al., [33] have reported higher level of oleic acid then present findings i.e. $68.97 \mathrm{~g} / 100 \mathrm{~g}, 75.37$ $\mathrm{g} / 100 \mathrm{~g}$. Walnut possess the $21.23 \mathrm{~g} / 100 \mathrm{~g}$ of oleic acid; such results were comparable to findings of [27] (16.85 to $26.44 \mathrm{~g} / 100 \mathrm{~g})$. Oleic acid is important for food and cosmetic industries Hulya et al., [34], moreover it has beneficial effects on human health including reduction in the level of serum triacylglycerides mainly LDL cholesterol which lower the risk of heart attack [35], authors have found oleic acid in the range 22.92 to 26.4 $\mathrm{g} / 100 \mathrm{~g}$ for various nuts from Turkey [36].

PUFAs from edible nuts are beneficial to human health regarding the cardiovascular system. Table 2 shows that in the current research PUFA content of selected different nuts were higher than MUFA and SFAs. The level of PUFA is found to be elevated in walnut $(72.14 \mathrm{~g} / 100 \mathrm{~g})$ in comparison to pine nuts $(55.00 \mathrm{~g} / 100 \mathrm{~g})$, peanut $(42.03 \mathrm{~g} / 100 \mathrm{~g})$, pistachio $(36.26 \mathrm{~g} / 100 \mathrm{~g})$ and in almond $(33.11 \mathrm{~g} / 100 \mathrm{~g})$.

Table 2. Fatty acid composition of total lipids from different nuts.

\begin{tabular}{lccccc}
\hline Fatty acids (g/100g) & Walnut & Almond & Pistachio & Peanut & Pine nut \\
\hline Palmitic acid & $4.36^{\mathrm{a}} \pm 0.01$ & $4.70^{\mathrm{c}} \pm 0.03$ & $5.37^{\mathrm{a}} \pm 0.05$ & $10.22^{\mathrm{d}} \pm 0.02$ & $4.54^{\mathrm{a}} \pm 0.01$ \\
Stearic acid & $1.92^{\mathrm{b}} \pm 0.02$ & $1.23^{\mathrm{a}} \pm 0.01$ & $1.25^{\mathrm{d}} \pm 0.11$ & $3.32^{\mathrm{c}} \pm 0.12$ & $3.31^{\mathrm{a}} \pm 0.05$ \\
$\sum$ SFA & 6.28 & 5.93 & 6.62 & 13.54 & 7.85 \\
Palmitolic acid & $0.20^{\mathrm{a}} \pm 0.00$ & $0.70^{\mathrm{a}} \pm 0.02$ & $0.53^{\mathrm{c}} \pm 0.03$ & $0.15^{\mathrm{b}} \pm 0.01$ & $0.22^{\mathrm{d}} \pm 0.04$ \\
Oleic acid & $21.23^{\mathrm{c}} \pm 0.01$ & $60.25^{\mathrm{a}} \pm 0.05$ & $56.51^{\mathrm{d}} \pm 0.01$ & $44.15^{\mathrm{a}} \pm 0.00$ & $36.79^{\mathrm{b}} \pm 0.05$ \\
$\sum$ MUFA & 21.43 & 60.95 & 57.04 & 44.30 & 37.01 \\
Linoleic acid & $57.26^{\mathrm{c}} \pm 0.09$ & $30.14^{\mathrm{a}} \pm 0.11$ & $33.25^{\mathrm{a}} \pm 0.03$ & $37.06^{\mathrm{d}} \pm 0.01$ & $48.19^{\mathrm{b}} \pm 0.07$ \\
Linolenic acid & $14.88^{\mathrm{a}} \pm 0.05$ & $2.97^{\mathrm{b}} \pm 0.05$ & $3.01^{\mathrm{c}} \pm 0.01$ & $4.97^{\mathrm{d}} \pm 0.05$ & $6.81^{\mathrm{a}} \pm 0.01$ \\
$\sum$ PUFA & 72.14 & 33.11 & 36.26 & 42.03 & 55.00 \\
\hline
\end{tabular}

Note: Each value is an average of fifteen samples, with its standard deviations. Different superscripts in the same row indicate significant differences $(\mathbf{p}<0.05)$ 
Similarly, Dorota et al., [26] also found higher level of PUFA in most nuts in response to MUFA and SFA and further reported comparable results of PUFAs in different edible nuts ranged 20.61 to $75.86 \mathrm{~g} / 100 \mathrm{~g}$. In present study total PUFA content is based on two FAs viz linolenic acid ( $n-3$ family) and linoleic acid ( $n-6$ family). Both FAs play important role in human nutrition, both of these FA cannot be synthesized endogenously. Clinical and epidemiological studies propose that the inclusion of different nut consumption in the diet had a significant protective benefit with respect to CHD, and showed they act as originator of several substances that control blood pressure, temperature, blood clotting, inflammation, regulation of cell differentiation, repair of DNA damage, immunological activity and various other functions [35].

The values of linoleic acid in different analyzed nuts were represented as $57.26 \mathrm{~g} / 100 \mathrm{~g}$ in walnut, $48.19 \mathrm{~g} / 100 \mathrm{~g}$ in pine nuts, $37.06 \mathrm{~g} / 100 \mathrm{~g}$ in peanut, $33.25 \mathrm{~g} / 100 \mathrm{~g}$ in pistachio and $30.14 \mathrm{~g} / 100 \mathrm{~g}$ in almond. Walnut showed the higher amount of linoleic acid, these results are in excellent agreement with some other researchers for walnut [32]. In present study walnut also possess higher amount of linolenic acid as compared to other nuts in order as, walnut have $(14.88 \mathrm{~g} / 100 \mathrm{~g})$, pine nuts $(6.81 \mathrm{~g} / 100 \mathrm{~g})$, peanut $(4.97 \mathrm{~g} / 100 \mathrm{~g})$, pistachio $(3.01 \mathrm{~g} / 100 \mathrm{~g})$ and almond $(2.97 \mathrm{~g} / 100 \mathrm{~g})$. Calculated value of linolenic acid for walnut were found similar with the research values (13.50 to $14.90 \mathrm{~g} / 100 \mathrm{~g}$ ) of Sara and Parisa [15] and (14.30 to $14.80 \mathrm{~g} / 100 \mathrm{~g}$ ) Mehmet et al., [36]. The analysis shows significant variation in the FA profile among the studied nuts. Such results can be elucidated by prior information that FA composition were based on different factors for instance size, variety, geological location, seasonal variations and maturity period, genetic, ecological, morphological, physiological, cultural factors, maturation, harvesting and soil properties [37].

Different ratios were calculated from present study which shows the FA quality of analyzed nuts; results are shown in Table 3 . Calculated ratio of $n-6 / n-3$ for walnut (3.85), pine nuts (7.07), peanut (7.46), almond (10.15) and pistachio (11.05). The benefits of a lower ratio of $n-6 / n-3$ include, $70 \%$ decrease in the death ratio of cardiovascular patients, reduction in asthma symptom and also reduce inflammation cause by rheumatoid arthritis [38]. In addition, determined vital FA ratio of $n-6 / n-3$ of walnut was found low in contrast to other analyzed nuts, lower $n-6 / n-3$ of walnut is valuable for nutrition purpose by providing more $n$ - 3 essential FAs in comparison of other analyzed nuts, which makes (walnut) seed as very healthy and nutritious. According to Simopoulos, this ratio must be between $4: 1$ and $1: 1$, walnut falls in such health beneficial recommended ratio (4:1). However, the calculated ratios of other nuts were higher than recommended level but results were comparable to the literature values (11 and 13.97) by Angela et al., [18].

Table 3. Nutritional quality among different selected nuts.

\begin{tabular}{lccccc}
\hline $\begin{array}{c}\text { Nutritional ratio } \\
\text { of FAs }\end{array}$ & Walnut & Almond & Pistachio & Peanut & $\begin{array}{c}\text { Pine } \\
\text { nut }\end{array}$ \\
\hline PUFA/SFA & 11.49 & 5.58 & 5.47 & 3.10 & 7.00 \\
PUFA/MUFA & 3.36 & 0.54 & 0.63 & 0.94 & 1.48 \\
$\mathbf{n - 6 / n - 3}$ & 3.85 & 10.15 & 11.05 & 7.46 & 7.07 \\
Oleic/Linoleic & 3.85 & 10.15 & 11.05 & 7.46 & 7.07 \\
Linoleic/Linolenic & 3.85 & 10.15 & 11.04 & 7.45 & 7.08 \\
Stearic/Palmitolic & 9.60 & 1.76 & 2.36 & 22.13 & 15.04 \\
& & & & & \\
Oleic/MUFA & 0.99 & 0.98 & 0.99 & 0.99 & 0.99 \\
\hline
\end{tabular}

The PUFA/SFA ratio of the analyzed nuts in present study were ranged as 3.10-11.49; minimum recommended level of this ratio is 0.45 , as suggested by the Department of Health and Social Security (DHSS, 1994) of England [35]. 11.49 was the maximum ratio of PUFA/SFA for walnut indicating higher amount of health beneficial and disease protective PUFA and lower amount of SFA as compared to other nuts. Comparable results were reported by Mohammad et al., [39]. Further walnut possess high PUFA/MUFA ratio 3.36 due to higher linoleic acid and lower oleic acid, however almond having opposite trend, comparable results (1.92-3.97) and (2.22-4.54) were reported by Cemile et al., [32].

Among present study some main outcomes have been acquired with respect of FAs correlations of nuts, negative correlation was 
identified in between oleic acid and linoleic acid as shown in Fig. 1a that almond, pistachio and peanut have higher level of oleic acid in response to linoleic acid however pine nut and walnut have inverse trend. The ratio of oleic and linoleic are shown in Table 3, result shows that almond contains high value (2.00) for oleic/linoleic ratio followed by pistachio (1.69), peanut (1.19), pine nuts $(0.76)$ and walnut $(0.37)$, which point out that the high oleic acid will liable for the lower level of linoleic acid and increase in ratio of oleic/linoleic, further it would exhibit longer shelf life, increase stability of oil and nutritional value [40].

Fig. 2 shows positive correlation in between linolenic acid and linoleic. Both FAs tend to decrease or increase, lowest value of linoleic/linolenic was calculated 3.85 in walnut as shown in Table 3; the lower values indicates more $n$-3 PUFA which are beneficial for human life. However negative associations were observed in between stearic acid and palmitolic acid as shown in Fig. 1b. In present result the level of stearic/palmitolic acid were ranged 22.13 - 1.76. Lower value of such ratio in almond indicates more MUFA.

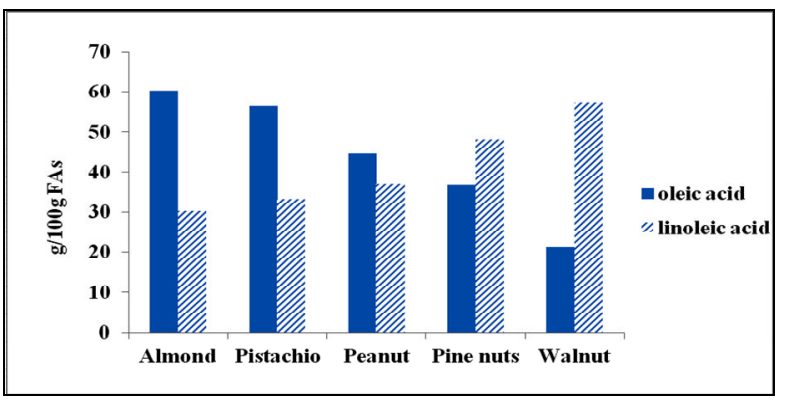

Figure 1a. Comparison of oliec acid and linoleic acid among different nuts

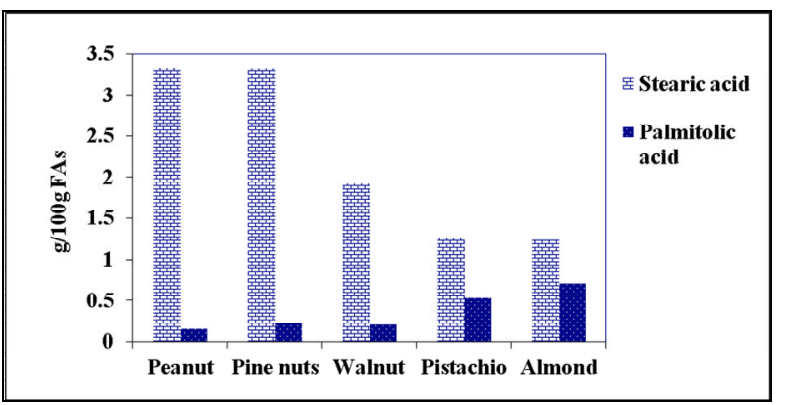

Figure 1 b. Comparison of stearic acid and palmitolic acid of selected nuts

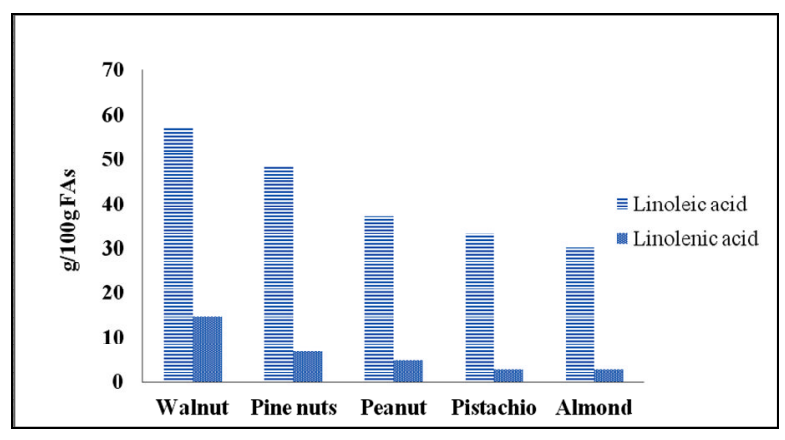

Figure 2. Comparison of linoleic and linolenic acid in different nuts

\section{Conclusion}

Edible nuts generally contains high level of proteins and oils, low level of moisture, minerals and ash, hence they are quit nutritious. They are a source of FA particularly n-3 (linolenic acid), n-6 (linoleic acid) and oleic acid, can be recommended for dietetic supplement to decrease the threat of cardiovascular syndrome. Besides that, all selected nuts contain high level of protein, good source of beneficial lipid and energy. The present experiment demonstrates that walnut is an excellent nutritionally resource of vital $n-3$ and $n-6$ fatty acids and significant amount of $n-6 / n-3$ ratio as compared to other analyzed nuts, which are nutritional beneficial to human health. PUFA/SFA ratio was also higher in walnut and indicates that walnuts are nutritionally favorable for consumption of diet. Walnut materializes to be quite beneficial in terms of composition of FA and their ratios and its consumption fulfill the high input of caloric value. FA characteristics of such sample indicated a great potential for marketing and future dietary investigation. Moreover, the knowledge offered from this research possibly will be beneficial for the industries related to food, cosmetic and pharmaceutics for selection of nuts oil.

\section{Acknowledgment}

National Centre of Excellence, University of Sindh, Jamshoro, Pakistan, is highly acknowledged for providing the research facilities for this study. 


\section{References}

1. S. Ahmad, Am. J. Food Sci. Nutr. Res., 2 (2015) 83.

2. A. Shaghayegh, M. Farzaneh, F. M. Seyedeh, H. S. Mohammad and Q. Mahnaz, J. Basic Appl. Sci., 2 (2012) 50. https://www.lifescienceglobal.com/pms/inde x.php/jbas/issue/archive

3. E. Patterson, R. Wall, G. F. Fitzgerald, R. P. Ross and C. Stanton, J. Nutr. Metab., (2012) 1. doi:10.1155/2012/539426

4. K. N. Ahmadi, S. A. Mortazavi, M. T. Ebrahimi, M. Hasani and M. Ghotbi, J. Food Biosci. Tech., 5 (2015) 1. http://jfbt.srbiau.ac.ir/article 6076 911407bc 6afe2b06a148a7c4a316fd9e.pdf

5. B. Cabanillas and N. Novak, J. Investig. Allergol. Clin. Immunol., 25 (2015) 329. http://www.jiaci.org/summary/vol25-issue5num 1257

6. P. B. Ayoola, A. Adeyeye and O. O. Onawumi, Am. J. Food Nutr., 2,3 (2012) 55. https://doi.org/10.5251/ajfn.2012.2.3.55.57

7. R. Masoomeh and M. J. Seid, Annals Food Sci. Tech., 12 (2011) 179.

http://www.afst.valahia.ro/images/document e/2011/issue2/full/sectioniii/2-MasoomehRaei-Seid-Mahdi-Jafari-1.pdf

8. M. S. Khalid, Pakistan Standards and Quality Control Authority (PSQCA) system. Ministry of science and Technology, Islamabad Pakistan.

www.npo.gov.pk/downloads/PQI_Presentati ons/PSQCA.pdf dated 19-06-2019

9. Association of Official Analytical Chemists. Official Methods of Analysis, 15th ed.; Helrich, K.; Mc Neal, J. E.; Eds.; AOAC: Washington, DC, (1990) 1. https://law.resource.org/pub/us/cfr/ibr/002/ao ac.methods.1.1990.pdf

10. IUPAC Standard Methods for the Analysis of Oils, Fats and Derivatives, 6th ed.; Paquot, C.; Ed.; Pergamon Press: Oxford, United Kingdom, (1979) 96.

https://old.iupac.org/publications/books/ISB $\underline{\text { N0632033371 compress.pdf }}$
11. A. B. Zamble, T. Z. Lessoy, W. A. A. B. Mireille, A. K. Celah and K. Rose, J. Appl. Biosci., 72 (2013) 5822. http://www.m.elewa.org/JABS/2013/72/4.pd f

12. I. Evaristo, D. Batista, I. Correia, P. Correia and R. Costa, Opt. Mediterr., 105 (2013) 99.

13. R. M. Patricia, A. C. Sofía, D. A. Lidia, G. O. Felipe and S. L. C. Madel, J. Mex. Chem. Soc., 58 (2014) 185. http://www.scielo.org.mx/pdf/jmcs/v58n2/v5 8 n2a15.pdf

14. G. Uzunova, N. M. Perifanova, M. Stojanova and S. Gandev, Bulg. J. Agr. Sci., 21 (2015) 494.

https://www.agrojournal.org/21/03-04.pdf

15. A. Sara and Z. Parisa, J. Agri. Environ. Sci., 14 (2014) 228. http://jaesnet.com/archive-jaes

16. A. Abdoshahi, S. A. Mortazavi, A. A. Shabani, A. H. Elhamirad and M. Taheri, Int. J. Nuts Rel. Sci., 2 (2011) 15. doi: 10.18869/acadpub.johe.3.4.242

17. K. M. Soheila, P. Bahman, A. Jaber and S. Fereshteh, J. Bio. Env. Sci., 6 (2012) 81.

18. C. R. Angela, H. P. D. Aloisio, M. Makoto, F. D. Laucia, M. T. Shawany and E. D. Nilson, J. Food Res., 2 (2013) 109. doi:10.5539/jfr.v2n1p109

19. D. E. Laura, L. Massimo, G. Paolo, A. Altero and L. Ginevra, Food Nutr. Sci., 6 (2015) 1267. doi: 10.4236/fns.2015.614132

20. N. Cevdet and D. Iclal, Food Chem., 86 (2004) 365.

https://doi.org/10.1016/j.foodchem.2003.09. $\underline{009}$

21. U. D. Akpabio, Adv. Appl. Sci. Res., 3 (2012) 2247.v

http://www.imedpub.com/articles/evaluation -of-proximate-composition-mineral-elementand-anti-nutrient-inalmond-terminaliacatappa-seeds.pdf

22. O. P. Olatidoye, S. S. Sobowale, J. V. Akinlotan and O. O. Olorode, J. Med. Appl. Biosci., 2 (2011) 1.

http://www.sciencepublishinggroup.com/jour nal/paperinfo?journalid=154\&paperId $=1000$ $\underline{5140}$ 
23. S. C. Udedi, O. N. Ani, B. N. Anajekwu, I. O. Igwilo, C. J. Ononamadu, C. S. Adindu and U. M. Okafor, The Biosci., 1 (2013) 114. http://www.bioscientistjournal.com/publicati on/2nd issue sept 2013/Comparative\%20Pr oximate\%20Analyses\%20of\%20Raw\%20an d\%20Cooked\%20Tetracarpidium\%20conop horum\%20\%28African\%20Walnut $\% 29 \% 20$ Found\%20in\%20Awka,\%20Anambra\%20St ate, $\% 20$ Nigeria.pdf

24. A. Elena and B. Gabriele, J. Food Sci., 31 (2013) 467.

https://doi.org/10.1016/S0268$005 X(13) 00009-X$

25. A. A. Isiaka, N. A. Violette and D. A. Olanrewaju, J. Food Agr. Environ., 10 (2012) 20.

https://doi.org/10.1234/4.2012.2521

26. D. Dorota, S. Ewa and W. Rafał, Pak. J. Bot., 46 (2014) 337.

https://pdfs.semanticscholar.org/2f76/7f8dd9 6364703359f6539e9cbc8114ed325f.pdf

27. U. Hulya, S. Ebru and S. Melekber, Erwerbs-Obstbau., 58 (2016) 11. https://doi.org/10.1007/s10341-015-0249-3

28. V. Mahesh and K. S. Shridhar, J. Agric. Food Chem., 54 (2006) 4705. https://doi.org/10.1021/jf0606959

29. K. Safa, K. Salih, T. Fatih, S. T. Omer, G. Umit, S. Osman, O. Nihat and G. Osman, $J$. Agric. Food Chem., 63 (2015) 2305. https://doi.org/10.1021/jf504390t

30. K. Huseyin, S. Ahmet, Y. Okkes and A. Abdullah, Turk. J. Biochem., 39 (2014) 307. doi: $10.5505 /$ tjb.2014.55477

31. J. S. Vassilia, F. S. Irini, K. Katerina, L. Dimitra, M. Constantino and Z. Panagiotis, J. Spectrosc., 1 (2015) 1.
32. Y. Cemile, Y. Sevil, E. Umran and K. Mihriban, Braz. Arch. Biol. Technol., 55 (2012) 677.

https://pdfs.semanticscholar.org/70c5/fa9f40 b04938166d9101de0835c43196699c.pdf

33. K. K. Jae, C. S. Eui, R. K. Cho, G. P. Gwi, J. C. Soo, Y. C. Hong and H. S. Dong, Food Sci. Biotech., 22 (2013) 1097. doi 10.1007/s10068-013-0189-3

34. N. N. Memon, F. N. Talpur, M. I. Bhangar and Aamna, Food Chem., 126 (2011) 405. https://doi.org/10.1016/j.foodchem.2010.10. 107

35. N. N. Memon, F. N. Talpur, M. I. Bhangar, Int. J. Food Prop., 13 (2010) 328. https://doi.org/10.1080/10942910802398479

36. M. O. Mehmet, I. Cesari and A. Derya, Agr. Sci., 1 (2010) 62. doi:10.4236/as.2010.12009

37. S. D. Dubey, K. Husain and M. Vajpeyi, Ind. J. Agr. Biochem., 14 (2001) 75.

https://www.researchgate.net/publication/28 7921907_Quality_of_linseed_Linum_usitatis simum_L_as_affected_by_soil_pH

38. C. A. Martin, V. V. Almeida, M. R. Ruiz, J. E. L. Visentainer, M. Matshushita, N. E. Souza and J. V. Visentainer, Rev. Nutr., 19 (2006) 761.

https://doi.org/10.1590/S1415$\underline{52732006000600011}$

39. S. T. G. Mohammad, S. M. Mohammad, H. Manuchehr, R. Karamatollah and K. Faramarz, J. Ind. Crop Prod., 45 (2013) 133. https://doi.org/10.1016/j.indcrop.2012.11.040

40. O. Kodad, J. M. Alonso and M. T. Espiau, $J$. Am. Soc. Horticul. Sci., 136 (2011) 273. https://doi.org/10.21273/JASHS.136.4.273 